\title{
A CONSTRUÇÃO DO SELF COMO POSSIBILIDADE DE LUTA POR RECONHECIMENTO: DO SUJEITO PSICOLÓGICO AO SUJEITO DE DIREITOS
}

\author{
Daniela Noronha Sampaio ${ }^{1}$; Carlos César Barros ${ }^{2}$ \\ 1. Bolsista PROBIC/UEFS, Graduanda em Psicologia, Universidade Estadual de Feira de Santana, e-mail: \\ noronhadaniela@hotmail.com \\ 2. Orientador, Departamento de Ciências Humanas e Filosofia, Universidade Estadual de Feira de Santana, e-mail: \\ carlosbarros@uefs.br
}

PALAVRAS-CHAVE: Reconhecimento; Auto-Imagem; Self.

\section{INTRODUÇÃO}

Esta pesquisa teve como base a análise crítica de Luta por Reconhecimento: A Gramática Moral dos Conflitos Sociais, de Axel Honneth (2003), diretor do Instituto de Pesquisa Social de Frankfurt, sob o seguinte questionamento: na necessidade de acompanhar o processo de desenvolvimento do sujeito psicológico em uma pessoa de direitos reconhecida socialmente, como a construção da auto-imagem (self) relaciona-se com o movimento de luta por reconhecimento?

O objetivo da pesquisa foi identificar e descrever os aspectos psicológicos existentes no processo construtivo da auto-imagem (self) social, associando-os à concepção de luta por reconhecimento em Axel Honneth; ao investigar a compreensão de auto-imagem em sua teoria, os conceitos de mim e self em George Herbert Mead (autor base para a compreensão de reflexões trazidas na obra de Honneth), relacionando a construção da auto-imagem com a definição de self e luta por reconhecimento. Estudos direcionados à compreensão de conceitos como auto-imagem, identidade social e luta por reconhecimento possibilitam um olhar crítico sobre o processo construtivo do reconhecimento jurídico e social da pessoa de direitos. Além disso, a pesquisa facilita o entendimento da busca por aceitação social de classes menos favorecidas e a evolução moral gradual de uma sociedade através da luta por reconhecimento.

\section{METODOLOGIA}

A presente pesquisa se caracteriza como revisão bibliográfica e se desenvolveu através da metodologia científica de Marconi e Lakatos (2006). O método utilizado se traduz, primeiramente, pela análise crítica de Luta por Reconhecimento: A Gramática Moral dos Conflitos Sociais, de Axel Honneth (2003), com a finalidade de investigar aspectos psicológicos que implicam e possibilitam a luta por reconhecimento social. Dentre esses aspectos, o atual trabalho tem seu foco no processo construtivo da auto-imagem, baseando-se no conceito de self de George Herbert Mead. Coloca-se, então, a obrigatoriedade de estudar a obra Mente, Self e Sociedade de George Herbert Mead (Morris, 2010) ${ }^{1}$, no propósito de explorar a construção da auto-imagem, juntamente com a sua concepção de self. Posteriormente, foi feita a análise da seção Mudança de paradigma em Mead e Durkheim: da atividade orientada por fins ao agir comunicativo, de Jürgen Habermas, presente no livro Teoria do agir comunicativo: sobre a crítica da razão funcionalista (Habermas, 2012) e de dois capítulos presentes em G. H. Mead e a Educação de Cledes Antonio Casagrande (2014), para um entendimento mais amplo acerca dos pensamentos de George Herbert Mead.

\footnotetext{
1 Charles W. Morris é o organizador da tradução para o português da obra Mente, Self e Sociedade de George Herbert Mead. Embora seja uma tradução da obra original, essa versão é referenciada no nome do organizador.
} 


\section{ANÁLISE E DISCUSSÃO DOS RESULTADOS}

Axel Honneth apresenta a psicologia social de George Herbert Mead na necessidade de exposição do seu pensamento acerca da luta por reconhecimento, e por considerar o pensamento de Mead como a própria "transformação naturalista da ideia hegeliana" (Honneth, 2003, p. 125). Para entender melhor essa transformação naturalista, Honneth retoma a filosofia de Hegel e demonstra que esses dois autores, Hegel e Mead, compartilhavam de idéias coincidentes, em seus respectivos contextos teóricos. Adotando a vertente naturalista, Mead possibilita a reconstrução da teoria hegeliana da intersubjetividade e se aproxima dos pensamentos de Hegel buscando na luta por reconhecimento a explicação para a evolução moral da sociedade.

$\mathrm{Na}$ intenção de buscar os mecanismos que fazem surgir uma autoconsciência da subjetividade nos seres humanos, Mead considera ser necessário primeiramente compreender o surgimento da internalização e consciência do significado das ações sociais e é partir daí que se organiza todo o seu pensamento, relevante para o aprofundamento do conceito de luta por reconhecimento em Honneth. Cledes Casagrande (2014) faz uma diferenciação pertinente acerca das definições de consciência e auto-consciência bastante utilizados nas obras de Mead e Honneth: a consciência seria a capacidade de reagir frente ao ambiente em que está inserido e com o qual interage, sendo assim, uma capacidade não só do ser humano; já a consciência de si, ou a capacidade de tornar-se self, só poderá ser desenvolvida em um ambiente social pois é através das interações sociais que o indivíduo pode ser autoconsciente.

Mead casa a teoria da comunicação com o surgimento do self ou autoconsciência, ao considerar que só o gesto vocal conseguiria desencadear no sujeito que age a mesma reação que o seu gesto causou no seu parceiro de interação (Honneth, 2003). Esse desencadeamento de reações similares e simultâneas pode indicar os mecanismos psíquicos que fazem a autoconsciência depender do processo social, por criar símbolos e significados comuns a mais de um indivíduo - desenvolvendo uma interpretação de suas ações de acordo com a percepção do grupo social em que está inserido e a capacidade de ser um objeto social não só para a comunidade, mas também para si mesmo (Morris, 2010).

É nas interações sociais, portanto, que um indivíduo aprende a se conceber da perspectiva do outro com quem interage. Aos poucos, nas várias relações de interação que vão se estabelecendo em comunidade, esse indivíduo passa a se perceber a partir de diversas perspectivas que formam uma noção generalizada das suas ações sociais. O outro generalizado - conceito bastante relevante na teoria de Mead - é essa reação generalizada de uma comunidade frente às atitudes dos seus membros, a qual pode ser traduzida pelo caráter normativo social, como a moral e as regras sociais.

O outro generalizado é internalizado na criança através das brincadeiras e jogos, os quais funcionam como exemplos da estrutura, cooperação e organização social; e ainda que Mead considere o outro generalizado como influente na atitude social do ser humano, existe uma parte do self que responde subjetivamente às normas assumidas pelos sujeitos. $\mathrm{O}$ mim $\mathrm{e} \mathrm{o}$ eu são duas fases do desenvolvimento do self descritas por Mead (2010): o mim é uma fase que age de acordo com a normatividade social importada pelo sujeito; e o eu é a atitude imprevisível e criativa do sujeito na ação social, que age de forma oposta ao mim.

À medida que o indivíduo é capaz de adotar as atitudes dos outros à sua volta, importando uma reação da comunidade frente à sua ação social e agindo tal qual o seu mim, que este pode, então, ser reconhecido socialmente e pertencer a determinado contexto. É ao constituir um self e ter esse self reconhecido que um indivíduo consegue se realizar. $\mathrm{O}$ eu também está inserido no processo de reconhecimento de determinado sujeito como self, quando como uma pessoa se afirma em contraposição a determinada convenção, norma ou preconceito, reivindicando direitos, por hora, restritos a ele. A reivindicação de uma 
comunidade mais ampla, ou a luta por um reconhecimento, se expressa muito através do $e u$, até porque essas reivindicações podem ser vistas como uma atitude do eu contra as manifestações do mim na busca por uma realização do self (terceira fase da construção do self). Esse conflito entre as duas fases do self representa, segundo Honneth (2003), o princípio para a evolução moral dos indivíduos e das sociedades na teoria de Mead.

\section{CONSIDERAÇÕES FINAIS}

A luta por reconhecimento está diretamente relacionada à construção da auto-imagem constituída durante o desenvolvimento dos sujeitos na situação social. A criança é pressionada a formar um self à medida que interage com a comunidade na qual está inserida; esse self é a própria auto-imagem trazida por Honneth (2003). A relação estabelecida entre auto-imagem, self e luta por reconhecimento foi um dos pontos principais para pensar a construção do sujeito psicológico como um sujeito de direitos reconhecidos socialmente e desenvolver o recorte temático do atual trabalho.

Quando se fala em luta por reconhecimento, é relevante mencionar que a evolução moral das sociedades que Mead (2010) descreve em sua teoria, Honneth (2003) considera como uma base na psicologia social para a ideia de luta por reconhecimento do jovem Hegel. Isso porque ao apontar o conflito entre eu e mim, Mead indica ser esse o motor para que haja o desenvolvimento das sociedades, e essa é a própria relevância da teoria de Mead para o pensamento de Honneth acerca da luta por reconhecimento.

\section{REFERÊNCIAS}

CASAGRANDE, C.A. G. H. Mead \& a Educação. Belo Horizonte: Autêntica Editora, 2014.

HABERMAS, J. Mudança de paradigma em Mead e Durkheim: da atividade orientada por fins ao agir comunicativo. In: HABERMAS, J. Teoria do agir comunicativo: sobre a crítica da razão funcionalista. São Paulo: Martins Fontes, 2012. p. 1-204.

HONNETH, Axel. Luta por Reconhecimento: A Gramática Moral dos Conflitos Sociais. $1^{\text {a }}$ Ed. São Paulo: Editora 34, 2003.

MARCONI, M.A.; LAKATOS, E.M. Metodologia do trabalho científico: procedimentos básicos, pesquisa bibliográfica, projeto e relatório, publicações e trabalhos científicos. $6^{\text {a }}$ Ed. São Paulo: Atlas, 2006.

MORRIS, C.W. (Org.). Mente, self e sociedade. Aparecida, SP: Ideias \& Letras, 2010. 